\title{
KRITIK SOSIAL DALAM KARYA SASTRA BENTUK NYATA PROTES SASTRAWAN
}

\author{
Neneng Wahyuni \\ STKIP Yayasan Abdi Pendidikan \\ nenengwahyuni38@gmail.com
}

Submit, 12-04-2019 Accepted,01-06-2019 Publish,04-06-2019

\begin{abstract}
ABSTRAK
Tujuan penelitian ini adalah untuk mendeskripsikan kritik sosial, bentuk nyata protes sastrawan terhadap permasalahan sosial melalui media karya sastranya. Metode yang digunakan adalah metode deskriptif. Hasil penelitian ini menemukan bahwa Wisran Hadi maupun Athur S. Nalan menyampaikan ketidaksukaannya terhadap fenomena sosial melalui naskah drama.Inilah yang dimaksud dengan bentuk nyata protes sastrawan melalui karyanya. Wisran Hadi melalui naskah drama Jalan Lurus menjabarkan kritiknya mulai dari permasalahan individu dengan karakternya sendiri, hingga permasalahan pemerintahan. Sedangkan Artur S. Nalan melalui naskah dramanya yang berjudul Sobrat secara garis besar yang mengkritik kebobrokan moral dan pola pikir yang tidak berkembang dari manusia, yang lebih tertarik pada daerah lain padahal di daerahnya dia bisa hidup lebih baik. Selain itu permasalahan moral yang diritik adalah tindakan manusia yang tidak lagi mengenal mana yang baik dan mana yang buruk. Simpulan, secara umum mereka menjabarkan ketidaksukaannya terhadap kebiasaan-kebiasaan buruk manusia dalam menjalankan hidupnya.
\end{abstract}

Kata Kunci: Kritik, Drama, Protes

\section{ABSTRACT}

The purpose of this study is to describe social criticism, a real form of man of letters protest against social problems throughher/his literary media. The method used is descriptive method. The results of this study found that Wisran Hadi and Athur S. Nalan conveyed their dislike of social phenomena through drama scripts. This is what is meant by the real form of literary protests through his work. Wisran Hadi through the drama drama"Jalan Lurus"describes his criticisms ranging from individual problems to his own character, to government issues. Whereas Artur S. Nalan through his draft text entitled Sobrat outlined which criticized the depravity of morals and a mindset that did not develop from humans, who were more interested in other regions even though in his area he could live better. In addition, moral problems are the actions of humans who no longer know what is good and what is bad. Conclusion, in general they describe their dislike of human habits in carrying out their lives.

Keywords: Criticims, Drama, Protest. 


\section{PENDAHULUAN}

Permasalahan pada penelitian ini adalah kritik terhadap permasalahan yang terdapat dalam karya sastra.Dalam penelitian ini.Tujuan penelitian ini adalah untuk mendeskripsikan kritik sosial yang terdapat dalam karya sastra bentuk nyata prostes sastrawan melaui media karyanya. Pada penelitian ini akan dijabarkan kritik yang ingin disampaikan Wisran Hadi melalui naskah drama Jalan Lurus terhadap permasalahan sosial yang ada di dalamnya. Selain itu di dalam penelitian juga akan melihat kritik sosial dalam naskah drama Sobrat karya Arthur S. Nalandengan demikian dapat diartikan pada penelitian ini mengkhususkan untuk melihat bagaimakan kritik sosial sebagai wadah protes oleh penulis naskah drama ini.Pembahasan tentang drama akanberkaitan dengan pembahasan naskah drama dan pertunjukan drama. Naskah drama berkaitan dengan seni sastra, sedangkan pertunjukan drama berkaitan dengan seni teater.Namun secara umum Hasanuddin (1996) menyatakan drama merupakan suatu genre sastra yang ditulis oleh pengarang dalam bentuk dialog-dialog yang memiliki tujuan untuk dituliskan sebagai suatu seni pertunjukan.Jadi drama berhubungan dengan naskah maupun pertunjukannya.

Kritik sosial terdiri atas dua kajian yaitu kritik dan sosial. Menurut Semi (1989) "Kata kritik berasal dari kritein, bahasa Yunani, yang berarti menghakimi, membandingkan, dan menimbang."Manusia hidup dalam masyarakat dengan proses sosial dan memenuhi kebutuhan secara bersama atau saling membutuhkan dan berhubungan.Kritik sosial secara umum biasanya digunakan sebagai kontrol untuk kehidupan sosial. Suhardi (2011) menyatakan penciptaan karya sastra jika dilihat dari latar belakang kelahirannya memiliki dua unsur utama, pertaman unsur hiburan dan kedua unsur kritik sosial pengarang terhadap realitas yang terjadi di sekelilingnya. Dengan kata lain pengarang dapat menjadikan karyanya menjadi wadah untuk mengkritik keadaan sosial yang menurutnya berada dalam keadaan yang tidak baik.

Dengan demikian tentu timbul pertanyaan, apakan sastra dapat mengubah masyarakat.Jika dianalisis sastra menjadi wadah sastrawan untuk mengkritik suatuhal tentu ada perubahan yang diinginkan oleh sastrawan tersebut terhadap keadaan masyarakatnya. Menurut Lubis (1997) sastra itu dapat berperan dalam proses perubahan karakter maupun pola hidup masyarakat. Dia dapat berperan sebagai alat pendorong perubahan masyarakat.Jadi kritik di dalam karya sastra yang dibahas disini bukan 
kritikan yang disampaikan oleh kritikus kepada sebuah karya sastra.Akan tetapi kritik yang dilihat adalah kritik yang disampaikan pengarang di dalam karya sastranya terhadap fenomena yang ada.Kritik sosial berarti kritik yang disampaikan pengarang di dalam karya sastra berhubungan dengan realita sosial yang tidak normal. Di dalam karyanya pun pengarang tidak mengkritik dengan lugas, akan tetapi pengarang mengkritik dengan bahasa kiasan sehingga meski memiliki tujuan mengkritik sastra tersebut tetap mempertahankan keindahan bahasanya.

Secara umum, kritik sosial hadir karena pertama, ketidakpuasan seseorang atau sekelompok orang terhadap suatu hal.Ketidakpuasan itu bisa saja disebabkan oleh perubahan sosial yang tidak sesuai dengan harapan.Hawley (dalam Sztompka, 2010) menyatakan perubahan sosial termasuk pada setiap perubahan yang tak terulang dari sistem sosial sebagai suatu kesatuan. Perubahan sosial ini mencakup konsep perbedaan pada waktu berbeda diantara keadaan sistem sosial yang sama sehingga kadang perubahan sosial itu tidak terterima oleh beberapa orang maupun kelompok. Selain itu, Havilan (1985) mengemukakan bahwa perubahan juga dapat terjadi pada perubahan kebudayaan meski berjalan dengan lambat.Perubahan ini juga menyebabkan hilangnya unsur-unsur kebudayaan yang berguna tanpa adanya penggantinya.

Kedua, kritik sosial di dalam drama juga disebabkan oleh ketidakpuasan terhadap stratifikasi sosial.Menurut Henslin (2006) stratifikasi sosial adalah suatu sistem dimana kelompok manusia terbagi dalam lapisan-lapisan yang ditentukan oleh kesuasaan, kepemilikan, dan prestise.Akan tetapi stratifikasi sosial ini tidak merujuk pada individu, melainkan merujuk pada kelompok manusia yang digolongkan ke dalam bentuk hirarki yang memberi hak istimewa pada mereka sesuai dengan tingkatannya. Keadaan ini menghadirkan berbagai permasalahan diantaranya sebagai berikut, a) Perbudakan, perbudakan ini merupakan pemilikan orang tertentu oleh orang lain yang biasanya terjadi kerena masalah utang, kejahatan, hingga perang, b) Kasta, kasta merupakan pemberian status yang ditentukan oleh kelahiran yang berlaku seumur hidup. Orang yang dilahirkan dalam kelompok yang berstatus rendah maka akan selalu menjadi rendah, c) Kelas sosial, kelas juga merupakan hal yang dimiliki seseorang sejak lahir. Namun kelas sosial ini dapat dirubah sesuai dengan apa yang dapat diraih.

Ketiga, kritik sosial di dalam drama disebabkan kegelisahan individu maupun masyarakat terhadap konflik ataupun permasalahan-permasalan yang ada di lingkungan 
sosial, misalnya pencurian, korupsi, pertengkaran, maupun bencana alam. Dengan kata lain, kritik sosial dapat hadir karena adanya permasalahan maupun konflik yang disebabkan interaksi manusia maupun alam.

Suatu perubahan tidak hanya memiliki efek yang baik bagi kehidupan sosial.Adakalanya perubahan itu menjadi suatu masalah yang patut mendapat perhatian.Selain perubahan stratifikasi sosial juga menjadi penyebab adanya kritik sosial. Karena adanya stratifikasi sosial maka orang-orang yang ada pada kelompok yang tinggi maka akan hidup dengan sejahtera. Namun, jika berada dalam kelompok yag rendah maka akan menjadi orang yang hidup tertindas dari orang lain. Hal inilah yang menghadirkan berbagai kritikan dari beberapa orang maupun kelompok yang peduli terhadap nasip kelompok rendahan yang selalu diperlakukan dengan tidak layak.

Adanya kririk yang dikemukakan oleh seseorang maupun kelompok tentu memiliki tujuan tertentu. Jika dianalisis berdasarkan teori penyebab terjadinya kritik sosial maka dapat dipahami bahwa dampak dari kritik sosial ini diharapkan dapat mengendalikan sosial. Menurut Henslin (2006) pengendalian mencakup pada pengendalian batin yang mencakup nurani dari individu itu dan pengendalian luar yang mencakup bantuan dari teman, keluarga, maupun pihak lain. Havilan (1985) menyatakan bahwa pengendalian dapat dilakukan oleh satuan politik ataupun masyarakat. Pengendalian ini bisa berupa pengendalian interen maupun pengendalian eksteren.Pengendalian interen mencakup kesadaran individu terhadap kebaikan dirinya sendiri.Sedangkan pengendalian eksteren merupakan pengendalian yang dilakukan oleh lembaga tertentu yang ditugaskan untuk pengendalian itu.

Suhardi (2011) yang menyatakan bahwa pengarang dapat melakukan tindakan untuk memperbaiki suatu keadaan yaitu melalui kritik sosial yang diciptakan melalui karyanya. Kritik itupun diharapkan dapat memberi gambaran kepada masyarakat untuk menuju arah yang lebih baik di masa yang akan datang.Dari penjelasan di atas dapat disimpulkan bahwa teori kritis merupakan landasan adanya kritik, terutama kritik sosial. Kritik itu akan ada karena adanya rasa tidak puas seseorang atau kelompok terhadap suatuhal. Kritik ini tentu juga dapat dilakukan oleh kelompok sastrawan melalui karyanya.Kritik ini disebabkan oleh perubahan yang berlebihan dan stratifikasi sosial.Tentu dampak yang diharapkan adalah perubahan yang lebih baik karena masyarakat mulai memahami keadaan yang tidak sesuai melalui kritikan itu.Kritikan 
yang disampaikan oleh kelompok sastrawan diharapkan dapat dibaca oleh kalangan masyarakat hingga pemerintah, sehingga dapat menciptakan gerakan pengendalian sosial.

Kritik sosial dapat dilakukan dalam berbagai aspek.Sesuai dengan prinsipnya yang menyatakan bahwa kritik sosial hadir karena adanya ketidakpuasan individu maupun kelompok terhadap gejala yang terdapat pada interaksi sosial.Horkheimenr (dalam Anwar, 2012) menyatakan dalam tindakan kritik dilatarbelakangi sifat kritis yang memiliki beberapa gagasan.Gagasan kritik dalam teori kritik mencakup beberapa permasalahan.Permasalahan tersebut dapat berupa persoalan moral atau etika, antropologi, pengetahuan, sejarah, logika atau nalar, ekonomi dan produksi, hedonisme, budaya, seni, dan sastra. Permasalahan dalam penelitian ini adalah bagaimana kritik sosial yang terdapat dalam karya sastra, untuk melihat aspek sosial mana yang diprotes oleh dua orang penulis naskah drama tersohor di Indonesia yaitu Wisran Hadi dan Arthur S. Nalan. Tujuan penelitian ini untuk menjabarkan bahwa sastrawan dapat menyampaikan protesnya terhadap permasalahan sosial melalui karyanya.

\section{METODE PENELITIAN}

Jenis penelitian ini adalah penelitian kualitatif. Penelitian kuatitatif adalah suatu penelitian yang mengutamakan proses atau kualitas dari apa yang diteliti.Metode penelitian yang digunakan adalah metode deskriptif. Metode deskriptif merupakan suatu metode yang dilakukan dengan cara menyampaikan suatu peristiwa yang urgen terjadi pada masa sekarang. Data pada penelitian ini adalah bentuk kritik sosial yang mewakili tindak protes sastrawan terhadap permasalahan sosial yang ditemukannya.Sumber data pada penelitian ini adalah naskah drama Jalan Lurus karya Wisran Hadi dan Naskah drama Sobrat karya Arthur S. Nalan. Dua naskah drama ini dipilih agar dapat menjadi perbandingan, bahwa tidak hanya satu orang penulis saja menaruh perhatiannya terhadap permasalahan sosial

Pada penelitian ini data dikumpulkan dengan cara membaca kedua naskah drama ini. Kemudian peneliti menandai secara garis besar apa yang dipermasalahkan atau diprotes oleh sastrawan dalam naskah dramanya. Kegiatan pengumpulan data ini dapat dibantu dengan adanya tabel inventaris data, yang berisa kolom tokoh dan dialognya. Kemudian melalui tokoh dan dialognya itu dapat ditulis masalah apa yang 
dikritik oleh penulis dalam karyanya itu. Misalnya masalah ekonomi, politik, atau masalah kebudayaan.Semua masalah dapat dimungkinkan, karena penulis berhak untuk menyampaikan protes atau kritik terhadap permasalahan apapun.

Cara menganalisis data pada penelitian ini adalah dengan menganalisis maksud dan tujuan mengapa penulis mengkritik hal yang sudah ditemukan dalam pengumpulan data. Penganalisisan ini dapat dilakukan dengan cara mengulas kembali kata maulupun kalimat yang disampaikan tokoh, dan menemukan apakan ada maksud tersirat dari dialog tersebut. Sehingga berdasarkan hal ini peneliti dapat menjabarjan dan memahami, apa yang menjadi permasalahan yang diprotes oleh Wisran Hadi dan Arthur S. Nalan.

\section{HASIL PENELITIAN}

Penelitian ini menemukan apa yang diprotes Wisran Hadi melalui naskah drama jalan lurus. Kritik tersebut adalah kritik terhadap permasalahan kebiasaan manusia sebagai individu maupun dalam kelompok, masalah pengetahuan, masalah kesepakatan, masalah perekonomian, masalah logika dan nalar, masalah kepercayaan, masalah hedonisme, masalah kebudayaan, masalah politik, masalah rumah tangga, masalah strativikasi sosial, masalah penyogokan, masalah ego manusia, masalah pemerintahan, masalah keagamaan, masalah korupsi, masalah etika dan moral, masalah emansipasi wanita, masalah keserakahan, masalah kesenian, masalah antrian, masalah kejujuran, masalah kebahasaan, masalah keamanan, masalah kepemimpinan, masalah pengharapan, masalah kebijakan, masalah kekacauan, masalah ketidakadilan, masalah kekerasan, dan masalah kepolisian. Pada bagian ini akan dijabarkan dialog-dialog yang memuat kritik tersebut.

Selain itu, dalam penelitian ini juga menemukan permasalahan yang dikritik oleh Arthur S. Nalan.Adapun secara garis besar yang dikritik oleh Arthur S. Nalan adalah kebobrokan moral dan pola pikir yang tidak berkembang dari manusia.Arthur $\mathrm{S}$. Nalan memulai kritikannya terharap pola pikir manusia yang hanya terfokus pada harapan untuk bisa kaya di rantau, namn akhirnya terjebak dalam dunia yang keras.Selain itu permasalahan moral yang diritik oleh Arthur S. Nalan adalah tindakan manusia yang tidak lagi mengenal mana yang baik dan mana yang buruk, sehingga perbuatan zina menjadi hal biasa bagi mereka. Berikut ini akan diulas satu persatu. 
Pada naskah drama Jalan Lurus karya Wisran Hadi terdapat beberapa permasalahan yang dikritik Wisran Hadi.Seperti yang telah dikemukakan pada bagian teori, bahwa kritik hadir berdasarkan teori kritis.Munculnya kritik kerena adanya ketidak puasan seseorang terhadap suatu keadan.Oleh karena itu, tidak menutup kemungkinan bahwa suatu kritik dapat juga dikritik oleh orang yang tidak suka terhadap suatu kritikan.Berikut ini adalah kritik sosial atau bentuk protes Wisran Hadi yang ditemukan dalam naskah drama Jalan Lurus.

Kritik terhadap Permasalahan Kebiasaan Manusia sebagai Individu maupun Kelompok.Kebiasaan manusia yang terbiasa hidup dalam kesalahanlah yang dikritik oleh Wisran Hadi.Manusia cenderung bersikap semaunya dan membenarkan sesuatu yang salah.Kebiasaan-kebiasaan yang dikritik dalam naskah drama ini termasuk ke dalam kebiasaan yang salah. Kritik terhadap permasalahan PengetahuanPermasalahan yang dikritik adalah masalah pengetahuan.Di dalam naskah drama Jalan Lurus ini mengkritik orang-orang yang memiliki pengetahuan yang minim namun berlagak seolah mereka tahu segalanya.Orang-orang seperti ini tidak mau diajarkan dan dinasehati. Kritik terhadap Permasalahan Kesepakatan.Pada kritikan ini Wisran Hadi bertukuan untuk mengkritik masyarakat yang telah mempermainkan kaesepakatan.Bahkan tidak jarang masyarakat menyepakati untuk membenarkan sesuatu yang salah.Kritik terhadap Permasalahan Perekonomian. Nurdin (2008:251—259) menyatakan kegiatan ekonomi merupakan semua kegiatan yang dilakukan menusia untuk memenuhi kebutuhannya yang beragam.Kenyataannya pada masa sekarang perekonomian masyarakat tidak stabil.Rakyat miskin semakin miskin, sedangkan yang kaya semakin kaya.

Kritik terhadap Permasalahan Logika atau Nalar.Logika berarti pengetahuan tentang kaidah berpikir dan jalan pikiran yang masuk akal.Nalar adalah pertimbangan tentang baik buruknya suatu hal.Naskah drama ini mengkritik keadaan masyarakat yang tidak menggunakan logika dan nalar ketika berpikir.Kritik terhadap Permasalahan Kepercayaan. Permasalahan yang dikritik adalah masalah kepercayaan.Orang-orang terlalu percaya pada mitos, tahayul, sejarah, dan makluk gaib.Kepercayaan mereka ini membuat orang-orang sering berbuat salah dalam menjalani hidupnya.Kritik terhadap Permasalahan Kebudayaan.Kebudayaan yang dikritik dikhususkan pada adat istiadat Minangkabau yang sudah memudar.Kritik 
terhadap Permasalahan Politik Masalah politik yang dikemukakan adalah karakter orang-orang yang berpolitik itu sendiri.Mereka saling menjatuhkan dalam mencapai tujuan politiknya.Dua kubu saling menyebutkan keburukan lawan politiknya.Selain itu politikus juga sering mengumbar janji tanpa bukti.Kritik terhadap Permasalahan Rumah Tangga.Permasalahan rumah tangga yang dikritik adalah hubungan suami istri.

Kritik terhadap Permasalahan Stratifikasi Sosial.Stratifikasi sosial adalah suatu sistem di mana kelompok manusia terbagi dalam lapisan-lapisan yang ditentukan oleh kekuasaan, kepemilikan dan prestise.Kritik terhadap masalah strativikasi sosial disampaikan melalui perbedaan peran lakon dengan lelaki pemanjat tiang.Kritik terhadap Permasalahan Penyogokan.Pada zaman sekarang banyak terjadi penyogokan. Penyogokan ini digambarkan melalui dialog tokoh yang protes karena orang yang di atas memberi pelincir di tiang listrik. Pelincir diibaratkan sebagai penyogokan.Kritik terhadap Permasalahan Ego Manusia.Manusia sering tidak peduli pada nasip orang lain yang berada di sekitarnya. Mereka hanya peduli pada urusannya masing-masing. Mereka tidak peduli jika orang lain tersakiti. Manusia rela bertengkar demi mencapai tujuannya.Tidak ada yang mau mengalah dan memaafkan.

Kritik terhadap Permasalahan Pemerintahan.Bagian yang diritik adalah oknum pemerintahan maupun keadaan pemerintahan itu sendiri.Pemerintah cenderung tidak memikirkan nasip rakyatnya.Permasalahan nasional seperti masalah ekonomi dan politik hitam sudak menjadi masalah yang biasa.Kritik terhadap Permasalahan Keagamaan.Permasalahan yang dikritik adalah masalah keagamaan.Banyak orang yang tidak memikirkan soal agama.Oleh karena itu tidak jarang diantara mereka melaksanakan larangan agama.Kritik terhadap Permasalahan Korupsi.Korupsi sudah menjadi penyakit masyarakat.Tidak hanya korupsi yang dilakukan oleh pejabat, namun korupsi kecil-kecilan juga dilakukan oleh masyarakat kecil.Korupsi inilah yang sulit untuk dihilangkan.Keadaan seperti ini yang dikecam keras oleh Wisran Hadi.Kritik terhadap Permasalahan Etika atau Moral.Etika dan moral manusia yang dikritik adalah etika dan moral yang buruk.Pada saat sekarang manusia tidak lagi memperlihatkan etika dan moral yang baik.Mereka tidak malu jika dikatakan tidak beretika.Masalah moral sudah dikesampingkan.Orang-orang hanya memikirkan kebahagiaan dan tujuan hidupnya. 
Kritik terhadap Permasalahan Emansipasi Wanita.Wanita pada zaman sekarang telah melupakan perannya sebagai wanita.Bahkan wanita pada zaman sekarang tidak segan-segan untuk meninggalkan kodratnya sebagai wanita.Wanita sudah serupa dengan laki-laki.Kritik terhadap Permasalahan Gender.Naskah drama Jalan Lurus karya Wisran Hadi menyampaikan kritik terhadap peran wanita yang tidak lagi diperhitungkan. Wanita tidak lagi dilibatkan dalam berbagai urusan kemasyarakattan. Kritikan tersebut disampaikan melalui dialog lelaki yang mencemooh ketika seorang lelaki datang memerankan peran perempuan. Kritik terhadap Permasalahan Keserakahan.Manusia selalu tidak puas dengan apa yang telah diperolehnya. Oleh karena itu manusia cenderung berbuat serakah.Keserakahan ini terlihat dari karakter lakon.Lakon selalu ingin menjadi siapapun yang bisa menguntungkan posisinya. Selain itu keserakah ini juga terlihat ketika lakon menguasai atasan dan tidak mengizinkan ara lelaki bicara dengan atasan. Kritik terhadap Permasalahan Kesenian.Seni merupakan kesanggupan akal untuk menciptakan sesuatu yang bernilai tinggi.Wisran Hadi mengkritik keadaan dimana kesenian telah mulai dilupakan.Kesenian yang menjadi ciri khas tidak lagi diabaikan.Manusia cenderung terpesona dengan hiburan lainnya.Perihal inilah yang dikritik oleh Wisran Hadi.Kritik terhadap Permasalahan Antria.Wisran Hadi mengkritik manusia yang cenderung tidak sabar.Ketidak sabaran ini dapat dilihat ketika manusia tidak mau antri. Orang yang belakangan datangnya malah ingin berada di posisi depan. Misalnya saja ketika mengambil karcis, ketika antri di kasir, dan lainnya.

Kritik terhadap Permasalahan Kejujuran.Orang-orang telah terbiasa untuk berbohong.Hakikat kejujuran tidak lagi ditanamkan dalam diri manusia. Selain itu manusia hidup dengan cara saling menipu. Kritik terhadap Permasalahan Kebahasaan.Dalam naskah drama ini dikemukakan bahwa bahasa masih sering dipermainkan oleh penggunanya.Bahkan tidak jarang bahasa tidak digunakan dengan baik. Masalah kebahasaan ini dihadirkan melalui dialog para tokoh. Tokoh sering mengatakan bahwa jangan mempermainkan bahasa, bahasa itu membingungkan, sebentar lagi bahasa akan hilang. Kritik terhadap Permasalahan Keamanan.Pada saat sekarang sulit untuk menemukan keadaan aman.Keadaan yang tidak aman ini juga menimbulkan perperangan. Misalnya saja perang antar suku yang sering dijumpai. Namun, yang disayangkan adalah keadaan yang risuh ini sering diabaikan oleh oknum 
yang harusnya bertanggung jawab.Kritik terhadap Permasalahan Kepemimpinan.Wisran Hadi mengkritik masalah kepemimpinan.Sulit untuk menjadi pemimpin yang jujur. Bahkan ketika pemimpin itu telah mundur dari kursi kepemimipinanya malah akan diketahui kesalahan-kesalahan yang diperbuatnya ketika memimpin.Kritik terhadap Permasalahan ideologi. Manusia terlalu banyak berharap.Selain itu manusia kadang berharap terlalu tinggi.Namun, mereka tidak berusaha untuk mewujudkan harapan mereka itu.Oleh karena itu Wisran Hadi meyampaikan kritikannya melalui karakter tokoh yang dihadirkanya.

Kritik terhadap Permasalahan Kebijakan Pemerintah.Wisran Hadi mengkritik kebijakan yang tidak lagi bijak.Terutama kritikan pada keadaan yang selalu menghadirkan kebijakan tanpa peduli apakah kebijakan itu bermanfaat bagi masyarakat.Kebijakan pada zaman sekarang hanya berpihak pada golongan yang mampu saja. Kritik terhadap Permasalahan Kekacauan.Keadaan pada zaman sekarang semakin kacau.Pemasalahan masyarakat sudah semakin banyak.Mulai dari masalah pribadi hingga masasalah kelompok. Bahkan ketika menyelesaikan suatu permasalahan, manusia masih saja berdebat tentang masalah apa yang mereka perdebatkan itu tanpa mencari penyelesaian dari masalah yang mereka hadapi. Kritik terhadap Permasalahan Ketidakadilan. Tidak adil dapat diartikan sebai berat sebelah.Wisran Hadi mengkritik permasalahan ketidakadilan. Ketidakadilan yang dimaksudkan oleh Wisran Hadi memposisikan sesuatuhal lebih berat dibanding yang lainnya atau dengan kata lain disaat seseorang disibukan dengan suatu hal, orang lain malah diberi keringanan. Manusia sering tidak adil pada manusia lain.

Kritik terhadap Permasalahan Kekerasan.Kekerasan sudah menjadi hal biasa. Menyakiti orang lain sudah bukan masalah lagi. Penganiayaan dan pembunuhan sudah menjadi hal yang lumrah. Kritikan terhadap kekerasan ini disampaikan melalui kegiatan pada lelaki dan dialog mereka. Mengancam untuk membunuh sudah biasa ujarkan.Kritik terhadap Permasalahan Kepolisian.Kritikan ini menyampaikan bahwa sangat sulit berurusan dengan oknum kepolisian. Bahkan polisi sering berupaya untuk memperbesar suatu masalah hukum. Banyak polisi yang mempermainkan masyarakat.Memperpanjang urusan masyarakat bahkan mempersulit masyarakat. 


\section{PEMBAHASAN}

Horkheimenr (dalam Anwar, 2012) menyatakan dalam tindakan kritik dilatarbelakangi sifat kritis yang memiliki beberapa gagasan.Gagasan kritik dalam teori kritik mencakup beberapa permasalahan.Permasalahan tersebut dapat berupa persoalan moral atau etika, antropologi, pengetahuan, sejarah, logika atau nalar, ekonomi dan produksi, hedonisme, budaya, seni, dan sastra. Permasalahan dalam penelitian ini adalah bagaimana kritik sosial yang terdapat dalam karya sastra, untuk melihat aspek sosial mana yang diprotes oleh dua orang penulis naskah drama tersohor di Indonesia yaitu Wisran Hadi dan Arthur S. Nalan. Semua kritikan yang dihadirkan Wisran Hadi dalam naskah dramanya hadir karena ketidakpuasan Wisran Hadi terhadap fenomena sosial yang dilihatnya.Wisran Hadi tidak terfokus pada satu masalah saja.Namun, ada beberapa masalah yang disampaikan Wisran Hadi dalam naskah drama Jalan Lurus.Sikap kritis Wisran Hadi ini dapat dibuktikan dengan adanya tiga puluh satu masalah yang dikemukakan wisran Hadi dalam naskah drama Jalan Lurus.Masingmasing masalah ini tentu memiliki penyebab dan dampak yang berbeda-beda.

Pada bagian awal naskah drama ini ada catatan yang diberikan oleh Arthur S. Nalan yang disebutnya sebagai catatan gelap. Arthur S. Nalan menyampaikan bahwa kisah ini diilhami oleh tragedi penambang emas liar di daerah gunung Pongkor, Jawa Barat, serta kejadian aneh yang dialami pembantunya pada tahun 80 -an yang bernama Jaman. Dia suka nomor buntut dan ia bermimpi bertemu dengan jin wanita di garasi rumah. Dia membisikan nomor jitu dengan syarat Jaman harus bersedia kawin dengan jin itu. Namun jaman mengingkari janjinya sehingga pada akhirnya Jaman menjadi bisu dan tuli. Melalui naskah drama ini Arthur S. Nalan juga ingin mempertegas bahwa kita masih menjadi bangsa kuli sampai sekarang, dan pengiriman TKI dan TKW tidak akan pernah berhenti.

Ketidak sukaan Arthur S. Nalan terhadap orang yang lebih tergoda dengan iming-iming kesenangan di darah lain dibanding berusaha di daerahnya sendiri dapat dilihat pada dialog beriktu ini. 
Sobrat : Beginilah hidup ku di Tapakdara ini! Jauh dari kampung lisung datang ke bukit Kemulau hanya untuk mengadu nasip menjadi kuli kontrak penambang emas. Padahal aku cukup bahagian bersama Mimi, ibuku. Mimi yang sangat telaten, suka memasak sayur asem untukku. Suka membuat pepes ikan untukku. Semua itu ku tinggalkan untuk emas. Kalau aku beruntung upak ku dapat, lalu habis dilantai judi dan biti-biti, lalu aku kontrak lagi. Aku selalu tergoda, sejak pergi tinggal tinggalkan kampung, sejak pergi dari tanah yang sebenarnya subur, sawah yang ledok, dan kebo yang montok.

Dari kutipan dialog tersebut, dapat dilihat kritik Arthur S. Nalan terhadap pemikiran orang yang menganggap rumput tetangga lebih hijau. Kritik ini disampaikan melalui dialog tokoh Sobrat yang menyesal dengan keputusannya meninggalkan kampungnya yang nyaman hanya untuk pergi mengejar harapan yang tidak pasti di daerah lain. Kritikan Arthur S. Nalan terhadap permasalahan ini diperkuat dengan kelanjutan kisah yang dialami Sobrat ketika tiba di kampung.Dia mengetahui bahwa ibunya meninggal setelah dia tiba di kampung.Sehingga Sobrat sangat menyesal. Melalui hal ini Arthur S. Nalan menjabarkan ketidak sukannya terhadap negara kita yang masih terus menerus mengirim TKI dan TKW meskipun kebanyakan banyak diantara TKI dan TKW yang menderita di sana.

Kritik yang disampaikan Arthur S. Nalan terhadap ketidaksukaan terhadap kebiasaan berjudi dapat dilihat dengan adegan para kuli yang menghabiskan uang yang dicarinya susah payah hanya dalam semalam di meja judi, sehingga hutang mereka bertambah banyak. Karena hutang semakin banyak, mereka terpaksa harus tetap menjadi kuli dan tidak bisa pergi dari tempat itu meskipun mereka ingin pergi.

Selain itu Arthur S. Nalan mengkritik terhadap moral yang sangat bobrok dengan percara pada hal-hal gaib.Kritik ini disampaikan melalui tokoh Sobrat yang lebih memilih untuk membuat kesepakatan dengan iblis. Namun, pada akhirnya Sobrat menjadi bisu dan tuli karena perbuatannya yang bersekongkol dengan iblis, Selain itu kritik terhadap moral ini paling tergambar melalui dialog tokoh dengan perempuan- 
perempuan yang diperjajakan di lingkungan mereka, yang memperlihatkan bahwa perempuan ini rela melakukan apapun untuk mendapatkan uang.

\section{SIMPULAN}

Kritik merupakan tidakan untuk menilai maupun mengomentari permasalahan maupun seseorang.Melalui naskah drama penulis dapat menyampaikan kritik maupun protesnya terutama terhadap permasalahan sosial.Baik Wisran Hadi maupunArthur S. Nalan berupaya menyampaikan bentuk protesnya dengan menggunakan kata-kata yang penuh kiasan. Secara umum mereka menjabarkan ketidaksukaannya terhadap kebiasaan-kebiasaan buruk menusia dalam menjalankan hidupnya.Wisran hadi menyampaikan kritik terhadap permasalahan kebiasaan manusia sebagai individu maupun dalam kelompok, masalah pengetahuan, masalah kesepakatan, masalah perekonomian, masalah logika dan nalar, masalah kepercayaan, masalah hedonisme, masalah kebudayaan, masalah politik, masalah rumah tangga, masalah strativikasi sosial, masalah penyogokan, masalah ego manusia, masalah pemerintahan, masalah keagamaan, masalah korupsi, masalah etika dan moral, masalah emansipasi wanita, masalah keserakahan, masalah kesenian, masalah antrian, masalah kejujuran, masalah kebahasaan, masalah keamanan, masalah kepemimpinan, masalah pengharapan, masalah kebijakan, masalah kekacauan, masalah ketidakadilan, masalah kekerasan, dan masalah kepolisian.

Sedangkan Arthur S. Nalanmengkritik kebobrokan moral dan pola pikir yang tidak berkembang dari manusia.Arthur S. Nalanmemulai kritikannya terharap pola pikir manusia yang hanya terfokus pada harapan untuk bisa kaya di rantau, namn akhirnya terjebak dalam dunia yang keras. Selain itu permasalahan moral yang diritik oleh Arthur S. Nalan adalah tindakan manusia yang tidak lagi mengenal mana yang baik dan mana yang buruk, sehingga perbuatan zina menjadi hal biasa bagi mereka.

Karya sastra menjadi media yang dapat menyampaikan perasaan dan kritikan terhadap suatu permasalahan. Saran yang dapat dikemukakan adalah, selama kritikan itu tidak disampaikan dengan cara yang menyinggung orang lain dan kasar, maka itu tidak akan menjadi masalah. Masalah akan timbul ketika penulis tidak mampu memlih kosa kata, sehingga kritikannya menjadi kritik yang menyinggung orang lain dan menghasilkan keributan, bukan solusi. 


\section{DAFTAR PUSTAKA}

Answar, Ahyar. (2012). Teori Sosial Sastra. Yogyakarta: Ombak.

Hasanuddin. (1996). Drama Karya dalam Dua Dimensi. Bandung: Angkasa.

Havilan, William A. (1985). Antropologi: Edisi Ke Empat. Jakarta: Erlangga.

Henslin, James M. (2006). Sosiologi dengan Pendekatan Membumi Jilid 2.Jakarta: Erlangga.

Lubis, Mochtar. (1997). Sastra dan Tekniknya.Jakarta: Yayasan Obor Indonesia.

Semi, M. Atar. (1989). Kritik Sastra. Bandung: Angkasa.

Sztompka, Piotr. (2010). Sosiologi Perubahan Sosial. Jakarta: Prenada Media Group.

Suhardi. (2011). Sastra Kita, Kritik, dan Lokalitas. Depok: Komodo Books. 